Social Work/Maatskaplike Werk Vol 56 No 3; Issue 3

http://socialwork.journals.ac.za/pub doi:http://dx.doi.org/10.15270/56-3-857

STAKEHOLDER ENGAGEMENT: ASSET-BASED COMMUNITY-LED DEVELOPMENT (ABCD) VERSUS THE TRADITIONAL NEEDS-BASED APPROACH TO COMMUNITY DEVELOPMENT

Hanna Nel

The research on which this article is based drew a comparison between the asset-based community-led development $(A B C D)$ approach and the more traditional needs-based approach to community development with regard to stakeholder engagement. The main finding of the qualitative study was that communities which were sensitised to $A B C D$ were more self-motivated, self-driven and self-organised, and utilised their own assets and resources in collaboration with external assets and resources. Participants adhering to this approach tended to spell out the kind of support they wanted from external stakeholders. In comparison, in the needs- and problem-based approach, community initiatives were dependent on external funds, while organisations driving the process felt responsible for the success of community initiatives.

Prof. Hanna Nel, Department of Social Work, University of Johannesburg, Johannesburg, South Africa.

Hanna Nel ORCiD Id: 0000-0003-1187-0450

hannan@uj.ac.za

Keywords: approach to community development, asset-based community-led development, community development, community development approach, stakeholder engagement, traditional needs-based community development approach 



\section{STAKEHOLDER ENGAGEMENT: ASSET-BASED COMMUNITY-LED DEVELOPMENT (ABCD) VERSUS THE TRADITIONAL NEEDS-BASED APPROACH TO COMMUNITY DEVELOPMENT}

\section{Hanna Nel}

\section{INTRODUCTION}

Community development is a crucial component of national development in South Africa, but what is the best way to engage stakeholders in community development? It is evident that the practice of community development has evolved from South Africa's unique history of the violation of human rights and of the inequality under colonialism and apartheid (Patel, 2015; Republic of South Africa 1996; White Paper for Social Welfare, 1997). It is recognised in legislation and in practice as necessary to address poverty and inequalities in South African society (e.g. National Development Plan; Batho Pele principles; the Sustainable Development Goals) (Republic of South Africa, 1996; Republic of South Africa, 1998; Republic of South Africa, 2000; World Bank, 2010). Community development refers to a process and method aimed at enhancing the capacity of communities to respond to their own needs and improve their capacity for development through recognising, mobilising, linking and strengthening community assets (Homan, 201; Ife \& Tesoriero, 2006).

Community development aims to enhance sustainable development in a way that engages community members, who take ownership of their own development and become self-reliant (Nel \& Pretorius, 2012; Pretorius \& Nel, 2012; Weyers, 2016). In community development initiatives and projects community members do not operate in a vacuum, but are usually engaged with networks and stakeholders in the mobilising and implementation of the projects. Stakeholders include, amongst others, community members, local organisations, institutions, clubs, associations, faith-based organisations, local government bodies such as municipal councils, funders, non-governmental organisations (NGOs) and community-based organisations (CBOs), local entrepreneurs and businesses. The nature of the engagement between the community projects and stakeholders makes a difference to the outcome of community initiatives. While examples of the successful application of ABCD in communities in general have been recorded (Braun, 2005; Hadidy, 2008; Yeneabat \& Butterfield, 2012), no formal evaluation has been conducted to determine differences in terms of stakeholder engagement in ABCD in comparison to the traditional needs-based approach. To address this paucity of research, a comparative qualitative study was conducted on the nature of stakeholder engagement in $\mathrm{ABCD}$ versus the traditional, more needs-based approach.

Previous research has shown that when stakeholder engagement with community members is driven by $\mathrm{ABCD}$ principles, the projects tend to be more sustainable than projects that are needs- and problembased in nature (Eliasov, 2013; Eliasov \& Peters, 2013; Green \& Haines, 2002; Hope \& Timmel, 1995; Nel, 2018a, 2018b; Schenck, Nel \& Louw, 2010; Ssewamala, Sperber, Zimmerman \& Karimli, 2010; Yeneabat \& Butterfield, 2012;). The purpose of the article is to present a comparison of the nature of stakeholder engagement in the two approaches to community development. It addresses the research question: What is the specific nature of stakeholder engagement in these two approaches? I argue that stakeholder engagement in the ABCD approach tends to enhance sustainable effort in communities in comparison to the engagement of stakeholders within a needs- and problem-based paradigm.

The article starts with a conceptual framework indicating stakeholder engagement within the context of the $\mathrm{ABCD}$ and problem-based approaches, followed by an explanation of the research methodology, discussions of the findings, conclusions and, finally, recommendations. 


\section{STAKEHOLDER ENGAGEMENT IN COMMUNITY DEVELOPMENT}

According to the literature, the two most common distinctions of the term 'community' are community as a place and community as a social construct which reflects shared interests and a feeling of belonging (Block, 2009; Preece, 2017). Development can be understood as a process or an outcome. For the purposes of this article, development is seen as an end goal of agency: "the capacity of people to order their world, the capacity to create, reproduce, change and live according to their own meaning systems" (Bhattacharyya, cited in Preece, 2017: 39). Community development is "the process of enabling this to happen" (Preece, 2017: 39). Community development can therefore be seen as a "collective approach to enhancing human agency" (Preece, 2017: 40). According to Brennan and Israel (cited in Preece, 2017: 40), agency can be described as "the capacity of people to manage, utilise and enhance those resources available to them". Based on the premise that a professional usually facilitates community development, and premised on the above, for the purposes of this article community development is defined as a "people-centred change process facilitated with a community of people to take action to increasingly actualise their fundamental human needs to enhance the quality of their own lives and those of the wider community that they are part of" (Schenck, Nel \& Louw, 2010: 6).

For community initiatives or projects to become sustainable, communities always work in collaboration with various stakeholders, both within and outside the community. In the article stakeholders are defined as persons who have an interest or stake in the development endeavours of a community (Swanepoel \& De Beer, 2011). Stakeholders can be identified at the levels of government, the private sector (such as shops, banks), non-governmental organisations (NGOs, development institutions), and the community sector (e.g. women's clubs, youth clubs, burial societies, clinics, school committees, traditional leaders and structures). The community and community members are the main stakeholders in community development.

What differentiates the $\mathrm{ABCD}$ approach from the problem-focused or the needs-based approach is the focus on strengths, capabilities and assets, on stimulating community-level organising and action, and on the role of different stakeholders as responsive co-investors and co-creators in community-level action. By using existing assets, strengths and capacities of communities (social, natural, cultural, financial, physical, human) as the starting point, the approach acknowledges citizens' contributions that have often been unnoticed or undervalued by development actors (Ashford \& Patkar, 2001; Braun, 2005; Homan, 2011; Landry \& Peters, 2018). If communities feel a sense of agency and ownership of their own destiny by using their existing assets and strengths as resources for change, then community members are more likely to accept external agencies as partners in the development process (Eliasov, 2013; Frediani, 2010; Preece, 2017). Adopting ABCD thus entails a shift towards encouraging and affirming community agency and ownership.

In contrast, development processes that are needs- and problem-based tend to patronise citizens as 'beneficiaries' and 'clients'. They address needs and problems with externally designed projects and programmes and often undermine local initiatives, with the result that projects have not been sustainable (Kramer, Amos, Lazarus \& Seedat, 2012; Landry \& Peters, 2018). Although these projects can make a difference in people's lives, they undermine local initiatives and involve the danger that no partnerships are established (Eliasov, 2013; Morse, 2011;).

If communities are not clear about what they want and what they are willing to contribute, then outside stakeholders may dictate what is required (Eliasov, 2013; Morse, 2011; Nel, 2018a, 2018b). Lobbying for access to resources is an important aspect of $\mathrm{ABCD}$, but it is important that communities form partnerships with relevant stakeholders and resources on terms determined by the communities and not the stakeholders. However, this is often not the case. The community members as a partner are often informed, or at best consulted, about project designs and budgets. There is often a lack of transparency. These projects may be described as 'locally owned', but often community members have little power or knowledge about the process. It could be a reason why many externally driven programmes are unsuccessful (Ashford \& Patkar, 2001; Hadidy, 2008; Ife \& Tesoriero, 2006; Kramer et al., 2012). 
Although communities determine the terms of engagement with external stakeholders, external stakeholders need to participate in these engagements.

It is therefore important for the community members and partners to be clear about the types of engagements they wish to create. These engagements and partnerships should be characterised by community members driving their own development by using their own assets, and then leverage activities, resources and investments from outside the community to support locally defined development while retaining control over the process (Nel, 2011; Nel 2018a, 2018b; Yeneabat \& Butterfield, 2012;). ABCD is thus an endogenous and not an exogenous process, using inside resources that the community members themselves build internally before supplementing them with outside resources.

$\mathrm{ABCD}$ places particular emphasis on social assets, which refer to the networks, connectedness and relationships of trust and reciprocity, practising the principles of ubuntu (an African word meaning "I am as strong as we are together"). Social assets provide the capability, motivation, control and power to act meaningfully and challenge the structural causes of poverty (Frediani, 2010; Landry \& Peters, 2018; Nel, 2018a, 2018b).

In the emerging literature on $\mathrm{ABCD}$ and stakeholder engagement, Landry and Peters (2018) mention the importance of building both horizontal and vertical forms of citizenship and accountability. The mobilisation of assets can increase the internal capabilities and capital of communities, which can be leveraged to attract investments from various 'outside' stakeholders (Frediani, 2010; Grobler \& Schenck, 2009; Whitney, Trosten-Bloom \& Rader, 2010). There is ample evidence of the effectiveness of $\mathrm{ABCD}$ in activating collective agency within communities and of the changes that take place in the community (Demeshane \& Nel, 2018; Nel, 2018a, 2018b), but there is less on the nature of the stakeholder engagement required for sustainable development (Landry \& Peters, 2018). This research will contribute to the debate and the limited literature on the nature of stakeholder engagement towards sustainable community practice.

Drawing on the discussion above, the six main principles of ABCD are the following: (1) change must come from within the community; (2) any engagement should focus on recognising what already exists in a community in terms of its assets; (3) the development goals should be ground-level and community-led; (4) an appreciative inquiry approach is required to understand, from the community perspective, which previous success stories can be built on; (5) change should be relationship-driven, rooted in local cultural traditions; and (6) the development process should be participatory and collaborative to ensure community ownership of decision making. Furthermore, in order to improve the collective process, civil society and other community-based organisations need to be involved as stakeholders in leveraging both their community members and external resources. In addition, citizen power should be built up to address structural inequities (Ashford \& Patkar, 2001; Kretzmann \& McKnight, 1993; Mathie \& Cunningham, 2003, 2005; Nel, 2011; Nel, 2018a, 2018b; Nel \& Pretorius, 2012; Preece, 2017; Landry \& Peters, 2018; Schenck et al., 2010).

\section{RESEARCH METHODOLOGY}

For the purpose of the research study on which this article is based, "ABCD-sensitised communities" refers to projects/communities in which all of the project members had some training in ABCD and applied ABCD knowledge and competencies in their projects/communities.

Projects/communities that are not sensitised to $\mathrm{ABCD}$ are communities/projects that have never heard about ABCD (or heard about it but did not know what the approach entails), and have had no formal engagement and training in $\mathrm{ABCD}$. These communities/projects primarily use other more traditional approaches in development, such as needs- and problem-based approaches. 


\section{Research approach}

This study followed an exploratory, descriptive and contextual strategy of inquiry within a qualitative paradigm in order to explore the nature of stakeholder engagement resulting from implementation of the ABCD and the traditional approaches (Delport, Fouché \& Schurink, 2011). The research question was: Does stakeholder engagement differ in $\mathrm{ABCD}$-sensitised communities and non-ABCD-sensitised communities?

\section{Research sample}

A non-probability convenient sampling technique was used to select the 24 projects/communities to be included in the research study: 14 sensitised to $A B C D$ and 10 not sensitised to ABCD. The following people were identified according to their experiences in the projects/communities: staff members of an NGO in Johannesburg involved in development work; members of an NGO Technical Support and Development Programme (TSDP); the lecturer (the author of this article) and four MA students of the University of Johannesburg (UJ); and a reference group from the Eastern Cape involved in ABCD projects/communities. Four provinces (Western Cape, Eastern Cape, Limpopo and Gauteng) were included in the study. The following criteria were used as a guideline for inclusion of projects/communities (Strydom \& Delport, 2011): projects/communities should have been in existence for at least two years; project leaders and members should be willing to participate in the research; and $A B C D$-sensitised project members should have had training in $A B C D$ and engaged in $A B C D$, whereas non-ABCD-sensitised project members had no training in $A B C D$ and no formal engagement in $A B C D$, but might have had some exposure to training in needs- or problem-based approaches to community development.

\section{Data-gathering tool and process}

To gauge the effect of the different approaches, a qualitative semi-structured interview schedule was used. The questions of the semi-structured interview schedule related to stakeholder engagement in general and not specifically to ABCD. Three master's students conducted interviews with persons who were involved in the projects or processes of development in the communities. Most of the interviewees were project leaders and project/community members and staff. The participants themselves decided how many persons would be interviewed per project or community. There were from 1 to 7 interviewees per project. In total, 24 face-to-face group interviews were conducted, most in African languages and some in Afrikaans (the latter in the Western Cape). The interviews were audio recorded.

\section{Data transcription, analysis and trustworthiness}

The interviews were transcribed verbatim by the three master's students and separately analysed by another master's student and the lecturer (the author of this article). In the data-analysis phase, a bottom-up inductive approach was utilised, moving from the specific to the general, using an informal, open-ended, exploratory approach (Delport \& De Vos, 2011). Thematic content analysis using codes, categories and themes was used to analyse the data (Creswell, 2004; Grbich, 2007; Henning, 2004). After the analysis, consensus was reached on the findings of the research by the main analyst (lecturer/author) and the researcher from TSDP.

For the purpose of ensuring trustworthiness I employed Guba's model of trustworthiness (Creswell, 2004; Lincoln \& Guba, 1985;). Two procedures were used to enhance the credibility of the data, namely analysis of data by two researchers (UJ lecturer/author and master's student) and reaching consensus on findings by two researchers (UJ lecturer/author and researcher from TSDP). I also used member checking to ensure credibility of findings.

\section{Ethical considerations}

Ethical clearance was received from the ethics committee of the Faculty of Humanities of UJ, and informed consent forms signed by the relevant persons. I requested permission to conduct interviews from the 24 organisations that facilitated the community initiatives or projects. It was also agreed that 
no names would be mentioned in the report. I also requested permission to record all interviews and to take photographs. A further commitment was made to share the final report with all the role players in the research project.

\section{Challenges experienced during the research process}

Some challenges were experienced during the data collection and analysis phases. Most of the interviews were done in various African languages and some in Afrikaans (in the Western Cape). They were subsequently translated and transcribed into English. The master's students found this process to be time-consuming and challenging. Adding to this challenge was the fact that the projects were spread over four provinces in South Africa and many of them were in rural areas, which posed logistical challenges in getting to the different sites.

Although the co-researchers were senior master's students, the training of the students in the qualitative procedures was time-consuming. However, they gained some expertise in a research methodology which is often underrated in terms of the complexity and intensity of the qualitative process. This was also the first exposure of the co-researchers to conducting fieldwork. Initially it was quite challenging for the students to get going, but once they had immersed themselves in the fieldwork, the process gained momentum. The mentoring and management of the students as co-researchers should therefore also not be underestimated.

\section{DEMOGRAPHIC INFORMATION}

Of the 14 sensitised projects, 6 were in rural communities, 6 in urban communities and 2 in peri-urban communities. Of the 10 non-ABCD-sensitised projects, 7 were in rural communities and 3 in urban communities. Interviews were conducted with 1 to 7 members of the sensitised projects. Individual interviews were conducted with 8 managers of the non-sensitised projects and a manager and staff member (two in total) of two of the non-sensitised projects. In total, 49 participants were included in the interviews of the ABCD-sensitised projects and 12 participants of the non-ABCD-sensitised projects. It is interesting to note that the number of participants involved in the interviews was usually more than one in the ABCD-sensitised projects, while in the non-sensitised projects usually only one person participated. The reason for this could be that $A B C D$ rates the values of inclusion and participation of many people as important, while the needs-based approach perhaps does not.

The nature and size of the projects and interventions were significantly diverse and can be briefly summarised as follows:

- income-generating projects, such as producing and selling of vegetables, producing and selling of plants (nurseries); brick-making and selling of bricks; selling of beadwork, cushions, knitted products, sweets, chips, snails; recycling; production of farming produce and selling of products such as chickens, cows, goats, eggs, honey;

- public works projects, building of infrastructure such as education centres;

- projects in health care, such as HIV and Aids counselling, awareness and home-based care, soup kitchens, food parcels, psycho-social support groups for adults and children, holiday programmes for children;

- education and wellness projects, such as life skills projects for women, children, youth and elderly people, gender sensitivity workshops, savings schemes, workshops on discipline of children for parents, computer literacy, maths and English classes, projects assisting people to access identity books, driver's licences, birth certificates and grants, awareness projects on human rights, office administration;

- projects with children with intellectual disabilities;

- projects in substance abuse (drugs and alcohol); and

Social Work/Maatskaplike Werk 2020:56(3) 
- projects on violence, such as rape, domestic violence, child abuse, woman trafficking.

\section{DISCUSSION OF FINDINGS}

Four themes emerged from the data analysis, namely relationships with stakeholders, networking and partnerships, funders, and entrepreneurship activities. Stakeholder engagement refers to the nature of participation by stakeholders and the role that stakeholders play in ABCD-sensitised and non-ABCDsensitised communities respectively. Community initiatives and projects are numbered and referred to accordingly in the direct quotations.

\section{Theme one: Relationships with stakeholders}

It was found that in ABCD-sensitised communities in general, the relationships between members of organisations driving development and stakeholders from outside were positive. Stakeholders tended to share their expertise and skills with community members of organisations driving community initiatives and projects. Many of these communities had support from local government. This was especially the case with municipalities and councillors, who showed interest in their initiatives and projects, and also attended meetings. The support was never financial in nature, but mainly involved providing resources such as venues, transport and food. A remark made in this regard was: "They don't give us direct money, but provide us with resources like venues, transport, food, etc." [P8]. This points to positive, trusting relationships between the stakeholders and members of community initiatives and projects. It further shows that stakeholders provided tangible support, which was identified by community members (Nel \& Pretorius, 2012; Pretorius \& Nel, 2012; Yeneabat \& Butterfield, 2012).

In some instances where ABCD-sensitised organisations did not have relationships with local government, they kept on approaching them. For example, two organisations had the confidence and tenacity to persist in inviting local government members to meetings and events. This shows that communities practising $\mathrm{ABCD}$ realise the importance of stakeholder relationships, the power that is situated in community members (Landry \& Peters, 2018), and the ultimate aim of community development, namely human agency (McKnight \& Block, 2010; Preece, 2017).

Community members and their organisations also engaged with government organisations to provide services, and address structural and other community needs. For example, the Department of Social Development was approached to deliver some services, and councillors were involved in the renovation of roads and housing, street cleaning projects, and the establishment of recycling projects. These actions are evidence of the kind of citizen agency power that can be built up and of the positive relationships with government (Landry \& Peters, 2018), as well as of the power within the ABCDsensitised communities - in contrast to the lack of power in non-ABCD-sensitised ones.

In some ABCD-sensitised communities meetings were often held with leaders/directors/managers of various organisations in the community to discuss issues, share experiences and discuss aspects of leadership. Some organisations even decided to form a leadership forum whereby leaders, managers and directors could meet with the purpose of sharing resources. The principle of ABCD as a participatory and collaborative approach between community members and stakeholders was demonstrated (Preece, 2017). The positive relationships (social capital) that existed between the community members and stakeholders in ABCD-sensitised communities were obvious (Block, 2009; Mathie \& Cunningham, 2003).

It was found that when organisations that applied non-sensitised ABCD approaches received funds from external institutions, community initiatives and projects were often driven by the community organisations (e.g. NGOs and CBOs, faith-based organisations) in collaboration with those external institutions (e.g. governmental organisations such as the Department of Social Development, the Department of Agriculture, and international organisations). The approach was often top-down in nature and the communities did not have much say. One of the leaders involved in these community organisations said, "I go to the municipality; we [management of the organisation] go to the nearby farmers for help; I need to get help from outside." [P16]. Limited involvement of and consultation with 
community members was noticed in the many negotiations between leaders and managers of community initiatives and projects and these outside stakeholders. It was evident that community members did not drive change and no ownership evolved from within the community (Ashford \& Patkar, 2001; Homan, 2011; Kretzmann \& McKnight, 1993; Mathie \& Cunningham, 2005).

In many non-ABCD-sensitised communities, the government did not really show an interest in what the communities were doing. In other instances, the NGOs and CBOs tried to involve government, but it seemed that government was not really interested in being involved. One of the responses as to why they did not involve government personnel was that "We wait too long for government-elected leaders." [P18]. Another remark was that government is too politically driven and only interested in the projects before elections. It seems if community-stakeholder relationships were not well established and that communities' contributions were not acknowledged (Hadidy, 2008; Mathie \& Cunningham, 2008; Preece, 2017).

The findings also showed that the projects/communities had limited cooperation with local NGOs, CBOs and businesses. The nature of cooperation with NGOs and CBOs was usually based on referrals from the projects, e.g. project members referred people to social workers.

Many of the non-sensitised communities/projects usually received support from organisations external to the communities as well as from international organisations. Grants and funds were received from the Department of Social Development, the Lotto, the Department of Land Affairs, Department of Water Affairs, and the Human Rights programme. These communities/projects were usually dependent on these funds. Community members were never involved in the allocation process of these funds. This is in contrast to the way in which ABCD-sensitised communities operated (Ashford \& Patkar, 2001; Mathie \& Cunningham, 2003; Nel, 2018a).

\section{Theme two: Networking and partnerships}

The nature of networking and partnerships was seen to differ in ABCD-sensitised and non-sensitised communities. In ABCD-sensitised projects and communities it was found that organisations formed partnerships with community members, specifically called 'learning partnerships'. These organisations engaged with the community members on an equal basis, and decisions were made democratically with the objective that community members take ownership of their initiatives and projects. Remarks in this regard from the organisations included: "We are learning partners ... people have to take ownership for their projects" [P4]; "... we try to make it as democratic as possible” [P6]; “... decisions are made in the monthly meetings where all members are present." [P7]. It seems as if managers and leaders in organisations driven by ABCD principles establish a collaborative process where both the community and stakeholders learn from each other, but the decisions finally rest with the community (Nel, 2018a, 2018b; Pretorius \& Nel, 2012;).

In $\mathrm{ABCD}$-sensitised projects and communities, networking with different stakeholders and forming partnerships with stakeholders were seen as very important. Participants felt that they did not want to duplicate services, but rather wanted to involve all possible stakeholders in various activities in the upliftment of their communities. They said that since they had applied ABCD, they were more 'connected' and worked together in an integrated way: "We are now in a space where we are together; we involve each other in training sessions and community action forums." [P8]. In the past they competed with each other for services and funds, but since the application of ABCD in their communities, they want to be connected and support each other in development endeavours. A remark made in this regard was: "When we started we embraced all the other NGOs and CBOs around here, we did not compete with them, but we networked with them." [P9]. ABCD is focused on networking with and including stakeholders with the aim of collaborating towards the betterment of the community (Nel, 2018a, 2018b; SSewamala et al., 2010;).

It was also found that project members tended to work with stakeholders as co-investors in a collaborative way. The terms of engagement, however, were determined by members of the community

Social Work/Maatskaplike Werk 2020:56(3) 
projects and properly discussed with the stakeholders. Remarks in this regard included: "We [project members] discuss the project with the NGO and explain what we need from them ... the community project is not here to receive money, but ask for specific assistance from the NGO." [P1]. Stakeholders in the ABCD-sensitised communities strove towards enabling communities to become the main drivers of development where they determine the stakeholders' terms of engagement, but they did this collaboratively with the stakeholders (Nel, 2018a, 2018b; Nel \& Pretorius, 2012; Pretorius \& Nel, 2012;).

It was interesting to see that local community members focused first on internal assets and capabilities to be utilised in the execution of projects and that when they experienced success, internal assets were supplemented with outside resources (Schenck et al., 2010). Remarks in this regard included: "She [external supporter] wants people to start their own initiatives and then she tops up" [P8]; "We have started mixing dough and making fat cakes using a paraffin stove, and then she buys a new paraffin stove and the paraffin on top of what we are already doing. " [P6]

Findings from the non-ABCD-sensitised communities/projects looked different from those communities that were sensitised to ABCD. Community organisations did network with external organisations, but primarily with the purpose of obtaining resources and funds for projects. The leaders of those organisations drove the process and took responsibility for seeking resources and funds. Remarks in this regard were: "If we [the organisation] want a project we just source funding from somewhere ... we need to have funds for the project ... we need to pay stipends to participants in the projects." [P15]. Managers and leaders of these organisations were the drivers of the projects, and managed the projects in an authoritative top-down manner, which is in contrast to ABCD principles (Nel, 2018a, 2018b).

\section{Theme three: Funders}

ABCD-sensitised organisations tended to drive their own development and work as partners with the funding organisations. It appeared that these projects/communities used their personal assets and assets in the communities, and did not rely on outside resources and funders. A remark in made this regard was: "Whenever we want to do something, we don't like to wait, so we work with what we have and those who are willing" [P1]. This quotation supports ABCD's notion of "you use what you have and work with where the energy is" (Nel, 2018a: 40).

Furthermore, organisations supported members of the community to invest in their own assets first, then look for funds and resources from outside. Funders also tended to provide tangible resources, or when they provided funds, they were to meet specific tangible needs of projects. Money did not drive development, but community members galvanised their own resources first in building their livelihoods (Mathie \& Cunningham, 2003). Comments from participants in the interviews confirmed this finding: "She [funder] wants people to start their own initiatives and then the funder tops up" [P4]; "The funder does not want to hear anyone asking for money but saying this is what we have done ... if they want to make fat cakes we must first start with the project and then the funder will add." [P4]

The analysis further revealed that community members of community projects think of funders as partners and co-creators of wealth - an important principle of ABCD (Kretzmann \& McKnight, 1993; Nel, 2011; Nel \& Pretorius, 2012; Preece, 2017; Nel, 2018a, 2018b; Schenck et al., 2010). The community members determined the rules of the partnership with funders. Activities in such communities expanded. They wanted to generate their own income and were not concerned about the funding from outside. A comment in this regard was: "We really work with what we have even if there is no funding" [P2]. Findings showed that there was a clear move from dependence to independence in these communities. A remark that revealed this independence was: "We got a bank account; and even when we get funders, they will see that we are active and not waiting to just receive.” [P2]

Organisations and communities/projects that were sensitised to ABCD were of the opinion that people in the communities did not approach organisations with an attitude that the organisations had the 
money and should help the communities/projects. They believed that people should take responsibility for their own development but would, in a partnership relationship, negotiate and decide what would be provided by the funder. A remark from a manager of an NGO was: "We are getting some money to assist with going by taxis to communities; we are able to get airtime to phone the project members" [P3]. Another comment in this regard was: "People don't come to us like we are the ones with the money and we should help them; they come to us as more free, for example, when people go to a funder and say please help us, we lack this or that, I feel this is not what is happening with us, we have changed from being that kind of organisation." [P7]. The views expressed above are evidence of the power of ABCD in establishing sustainability in communities (Nel \& Pretorius, 2012; Nel, 2018a; Pretorius \& Nel, 2012).

It was interesting to hear from $\mathrm{ABCD}$-sensitised organisations that the way in which they had originally operated had been very stressful, but since ABCD was introduced, the burden on the organisations had lessened. Previously, they were always under pressure to provide and render services as well as to raise funds for projects. Since being introduced to $\mathrm{ABCD}$, the organisations did not act to address the needs in the community by providing projects and services, but rather acted as co-investors and co-creators of wealth in the communities. The communities also used their own resources first and supplemented their resources with outside resources: "We received a bit of funding from USAID but that was only for the irrigation system we use in the gardens; almost everything you see here was done by women who had passion to make a difference; we do not promote the dependency way of life" [P8]; "We have a bank account now; we did that with the help of the organisation. At the beginning of every month we each contribute R20 into the account just to ensure that it stays open and valid; we use the money towards our project." [P1]

Organisations that were not sensitised to $\mathrm{ABCD}$ were primarily driven by funds received from external resources. The primary focus of those NGOs and CBOs was to look for funds to be able to provide services to communities, and drive projects for them. Funds from outside were very important to them. Remarks in this regard included: "Funds are very important to do our work effectively ... we will not make it without funds from outside" [P17]; "This office runs on a day-to-day basis; projects do not usually happen; if we want a project, we just source funding from somewhere" [P19]; "They pay grants to us to run our project" [P22]; "Fifty-two people eating at the soup kitchen, and if it is not there, where will they get food? People will starve of hunger." [P24]

These comments are an indication of the responsibility organisations took to run projects without requiring or developing much responsibility from the communities themselves. These organisations and communities/projects often did not take full ownership of their development but relied on external assistance, and especially funders. They perceived sustainability as a state when funds are constantly being provided from outside; managers of these organisations and projects constantly looked for funds. Remarks in this regard included: "It will be helpful if we can win the Lotto, to do development for the community" [P22]; "... we need money for that" [P21]; "... we have to close the project when the funding stops at the end of this month" [P19]; "... waiting for funders, we render services, funding is very important to run the project, we serve the community, we (are) reaching out." [P20]

Findings also showed that funders, in collaboration with the management of these NGOs and CBOs, determined what they were going to spend their money on, what the main priority need was and what the outcomes should be. Little input from communities was required. Often funds covered the administration of these organisations as well as salaries of managers involved in these organisations. It was also found that huge amounts of money were spent on training of community members. People did find that they were empowered through the training, but the emphasis was not on the application of these skills to establish independent community projects.

It was evident that the more funding projects received, the more dependent they were on money from outside and the less they talked about striving towards independence in terms of financial assistance: 
"We receive from the West Coast Community Foundation" [P17], "the Human Rights Programme" [P20], "the Department of Land Affairs and Water Affairs" [P21], and "the Lotto" [P24]; "We will not be able to carry on if the funds stop coming in." [P17]. Such comments indicate a clear approach of organisations and funders who are not ABCD-sensitised. This highlights the role that organisations play in collaboration with funders (Russell and Smeaton, 2010).

\section{Theme four: Entrepreneurship}

More small informal businesses were established in ABCD-sensitised communities than in nonsensitised ABCD communities. Many participants were of the opinion that they could supplement their social grant with extra income through the small businesses.

Another result of ABCD-sensitised communities was that people worked together and shared their resources towards building wealth in the communities. They tended to rely less on external resources. What they did was to support each other's businesses in their own communities as well as in neighbouring communities. Remarks in this regard were: "For example, bought poles from a project that produce poles and do not go to the 'big' shops... That community comes to buy seeds from us so we are doing business together." [P6]

It was also found that NGOs from outside came to assist with creating small businesses, but focused on projects that had already been established: "University approached us because they saw us selling vegetables and other stuff here in the community and they wanted to help us... They came and helped us to start the project and then they told us that they leaving us to continue on our own; this gave us the chance to do things ourselves, to learn more about these projects and be the actual owners and decide everything that happens." [P1]. Outside organisations did not take responsibility for the small businesses, but gave assistance to a certain extent; they withdrew and allowed the members of the businesses to proceed and take responsibility. This is a confirmation of the role of the local community as the decision-makers and the ones who supplemented resources for their activities while retaining control over the process.

In non-ABCD-sensitised communities it was found that organisations that focused on the development of small enterprises, job creation and co-operatives tried to assist these communities in becoming independent small business enterprises. Examples of these were recycling projects, crèches and spaza shops (local informal small businesses). However, not many of these small businesses became sustainable, independent businesses - many of them depended on funds from the organisation for operational purposes (Green \& Haines, 2002, Mathie \& Cunningham, 2003, 2005).

Based on the findings, the contrasts of the two approaches in terms of the nature of stakeholder engagement are summarised in Table 1.

\section{TABLE 1 \\ SUMMARY OF FINDINGS FROM THE ABCD AND THE NEEDS- AND PROBLEM- BASED APPROACHES IN TERMS OF THE NATURE OF STAKEHOLDER ENGAGEMENT}

\begin{tabular}{|l|l|}
\hline ABCD approach & Needs- and problem-based approach \\
\hline Community members are the main stakeholder. & $\begin{array}{l}\text { The main stakeholder is the organisation from where } \\
\text { projects and initiatives are launched. }\end{array}$ \\
\hline $\begin{array}{l}\text { Community and stakeholders are learning } \\
\text { partners, co-investors and co-creators. }\end{array}$ & Organisations and funders are the main investors. \\
\hline $\begin{array}{l}\text { Assets, capabilities and strengths of community } \\
\text { members drive the development process. }\end{array}$ & Money from funders drives the development process. \\
\hline $\begin{array}{l}\text { Informal relationships and trust exist between } \\
\text { communities and stakeholders. }\end{array}$ & $\begin{array}{l}\text { Formal relationships exist between communities and } \\
\text { stakeholders. }\end{array}$ \\
\hline $\begin{array}{l}\text { Organisation and community members are } \\
\text { learning partners. }\end{array}$ & $\begin{array}{l}\text { Organisations see community members as recipients of } \\
\text { services. }\end{array}$ \\
\hline
\end{tabular}


Terms of engagement of stakeholders are determined by the community.

Development involves various stakeholders, is collaborative in nature and has a ripple effect on the community.

\section{CONCLUSIONS}

In terms of the research question - namely, what would be the best way to engage stakeholders in community development - it could be concluded that the ABCD approach provides guidelines on how stakeholders could be engaged in community development initiatives and projects.

In this research study it became clear that the role stakeholders played in ABCD-sensitised communities led to self-motivated, self-driven, self-organised and sustainable initiatives and projects. Communities determined their own needs and dreams, and defined the plans they wanted to realise. It can therefore be concluded that by investing in their own assets and experiencing success personally, communities experience power from within themselves and their communities, and are thus capable of engaging with external stakeholders. The communities and their organisations involved in the study saw stakeholders as learning partners, co-investors and co-creators of wealth. These organisations did not approach stakeholders to ask for resources (both tangible and non-tangible, both inside and outside of the community), including funds, but they negotiated and decided collaboratively, in a partnership relationship, what would be provided by the stakeholder. In such a situation, power is distributed among community members and within the community, and not located in the organisations and external stakeholders.

It can be concluded that community development initiatives are an integrated approach where community members and stakeholders are involved as co-investors and co-creators of their future. Resources are shared widely in the community through networking. The collaboration of stakeholders, with the community being the main stakeholder, is based on trust, openness and transparency - both horizontally (in the community) and vertically (with stakeholders).

Non-ABCD-sensitised communities that participated in the research seemed to be managed mostly in a top-down, authoritarian manner. Managers and staff of these organisations focused on needs and problems of the communities, and tended to see themselves responsible for the success of projects in the communities. They perceived themselves as the main stakeholders in the development process. They saw themselves as owners of the initiatives and projects, and the success of the initiatives and projects were directly linked with the services they rendered to the communities. Community members were often informed about development programmes designed from outside.

In non-ABCD-sensitised communities, funders collaborated with management of the organisations in determining what they intended to spend their money on, and what the outcomes should be, with little input from communities. Often funds also covered the administration of these organisations as well as salaries of managers and/or stipends for people involved in these organisations. Vast amounts of money were spent on training of community members. The more funding that projects received, the more dependent they were on money from external role players and the less they strove towards achieving financial independence.

Funding was a major item in those communities that were not ABCD sensitised. Organisations relied primarily on funds from outside and projects were usually driven by the organisation and less by the community members. It seemed that when community members were primarily driven by organisations that were dependent on external funds, people were reluctant to start their own independent incomegenerating projects.

The approach to development of the non-ABCD-sensitised organisations was one of seeking funds with the purpose of rendering services to the community. The project management primarily saw 
sustainability as the ability to source funding for providing services to communities, to train community members and to earn a stipend or income.

It can be concluded that organisations that are sensitised to ABCD perceive stakeholders, people, development and change differently. People were not seen as clients, beneficiaries, service users or consumers, but rather as learning partners, co-investors and co-creators of independent sustainable livelihoods.

\section{CHALLENGES OF THE ABCD APPROACH}

The needs- and problem-based approach does indeed bring about changes in communities, but the process is not community driven and its sustainability is questionable. The needs-based approach is deeply rooted in the society, and hence the difficulty of people transitioning to an ABCD approach when they have become used to the needs-based approach is that it requires a change in mindset. Bringing about such a change is challenging and calls for capable and resourceful organisers and facilitators. It requires a mindset change not only at community level and within the organisation that drives the process, but at all levels of society, including all the stakeholders, such as government, funders and the business community.

\section{RECOMMENDATION}

The findings presented above provide practice and theory guidelines for stakeholder engagement within the context of sustainable community development. It is therefore recommended that stakeholders, such as government, businesses, NGOs, CBOs and civil society should see community members as the main stakeholder of development, and in partnership with the community in which they should co-invest and co-create sustainable community initiatives. It is recommended that a similar study to this one be conducted on a broader basis in South and southern Africa. Detailed stakeholder engagement guidelines need to be developed on the co-creation and co-investment of different stakeholders for asset-based and community-led communities.

\section{REFERENCES}

ASHFORD, G., \& PATKAR, S. 2001. The positive path, using appreciative inquiry in rural Indian communities. Myrada: Department for International Development (DFID), International Institute for Sustainable Development (IISD).

BLOCK, P. 2009. Community, the structure of belonging. San Francisco: Berrett Koehler Publishers.

BRAUN, A.R. 2005. Beyond the Problem-solving approach to sustainable rural development. In: GONSALVES, J., BECKER, T., BRAUN, A., CAMPILAN, D., DE CHAVES, H., RIVACACAMINADE J., \& VERNOOY, R. (eds). Participatory research and development for sustainable Agricultural and natural resource management a Sourcebook Volume 1: Understanding participatory research and development. Canada: International Potato Center-Users' Perspectives with Agricultural Research and Development and International Development Research Centre: 129135.

CRESWELL, J. W. 2004. Qualitative inquiry and research design. London: Sage Publication.

DELPORT, C.S.L., \& DE VOS, A.S. 2011. Professional research and professional practice. In: DE VOS, A.S., STRYDOM,, C.B., \& DELPORT, C.S.L. (Eds). Research at grass roots. For the social sciences and human service professions. $\left(4^{\text {th }} \mathrm{ed}\right)$. Pretoria: Van Schaik Publishers.

DELPORT, C.S.L., FOUCHÉ, C.B., \& SCHURINK, W. 2011. Theory andlLiterature in qualitative research in DE VOS, A.S., STRYDOM, C.B., \& DELPORT, C.S.L. (Eds). Research at grass roots. For the social sciences and human service professions $\left(4^{\text {th }}\right.$ ed). Pretoria: Van Schaik Publishers. 
DEMESHANE, J., \& NEL, H. 2018. An application of the process of appreciative inquiry in community development: An example from Soweto, South Africa. South Africa Southern African Journal of Social Work and Social Development, 30 (3): 1-17. SA accredited journal. https://doi.org/10.25159/2415-5829/3599

ELIASOV, N. 2013. Asset Based and Citizen led Development (ABCD), ABCD training of trainers' toolkit. Canada: Zanolele Inspiritual Creations.

ELIASOV, N., \& PETERS, B. 2013. Voices in harmony, stories of community-driven development in South Africa. Canada: Coady International Institute.

FREDIANI, A.A. 2010. Sen's capability approach as a framework to the practice of development. Development in Practice Journal, 20(2):173-187.

GRBICH, C. 2007. Qualitative data analysis: An introduction. London: Sage.

GREEN, G.P., \& HAINES, A. 2002. Asset building and community development. Thousand Oaks: Sage Publications.

GROBLER, H., \& SCHENK, R. 2009. Person-centred facilitation, process, theory and practice. Cape Town: Oxford University Press, Southern Africa.

HADIDY, W.E. 2008. Possibilities for income-deprived but capability-rich communities in Egypt. In: MATHIE, A. and CUNNINGHAM, G. (eds). From clients to citizens, communities changing the course of their own development. Warwickshire: Practical Action Publishing.

HENNING, E. 2004. Finding your way in qualitative research. Pretoria: Van Schaik.

HOMAN, M.S. 2011. Promoting community change, making it happen in the real world. Australia: Brooks/Cole, Cengage Learning.

HOPE, A., \& TIMMEL, S. 1995. Training for transformation: A handbook for community workers. Gweru: Mambo Press, Book 1.

IFE, J., \& TESORIERO, F. 2006. Community development, community-based alternatives in an age of globalization $\left(3^{\text {rd }}\right.$ ed). Australia: Pearson.

KRAMER, S., AMOS, T., LAZARUS, S., \& SEEDAT, M. 2012. The philosophical assumptions, utility and challenges of asset mapping approaches to community engagement. Journal of Psychology in Africa, 22(4): 537-546.

KRETZMANN, J.P., \& MCKNIGHT, J.L. 1993. Building communities from the inside out. A path toward finding and mobilizing a community's assets. Evanston: Center for Urban Affairs and Policy Research.

LANDRY, J. \& PETERS, B. 2018. Assets on the right(s) track? Reflections at the intersection of human rights-based approaches and asset-based and citizen-led development. Innovation Series No. 19. Antigonish: Coady International Institute.

LINCOLN, Y.S., \& GUBA, E.G. 1985. Naturalistic Inquiry. London: Sage Publications.

MATHIE, A., \& CUNNINGHAM, G. 2003. From clients to citizens: Asset-based community development as a strategy for community-driven development. Development in Practice, 13(5): 474486.

MATHIE, A., \& CUNNINGHAM, G. 2005. Who is driving development? Reflections on the transformative potential of asset-based community development. Canadian Journal of Development Studies, 26(1): 175-186.

MATHIE, A., \& CUNNINGHAM, G. 2008. (eds). From clients to citizens, communities changing the course of their own development. Warwickshire: Practical Action Publishing.

Social Work/Maatskaplike Werk 2020:56(3) 
MCKNIGHT, J., \& BLOCK, P. 2010. The abundant community. Illinois: Berrett: Koehler Publishers.

MORSE, S. 2011. Communities revisited: The best ideas of the last hundred years. Published online in Wiley Online Library (wileyonlinelibrary.com).

NEL, J.B.S. 2011. An application of appreciative inquiry in community development in South Africa. The Social Work Practitioner-Researcher/ Die Maatskaplikewerk Navorser-Praktisyn, 23 (3): $343-362$.

NEL, H. 2018a. A comparison between the asset-oriented and needs-based community development approaches in terms of systems changes. Practice: Social Work in Action, 30 (1): 33-52. Taylor \& Francis. IBSS journal. https://doi.org/10.1080/09503153.2017.1360474

NEL, H. 2018b. Community leadership: A comparison between Asset-based Community-led Development (ABCD) versus the traditional needs-based approach. Development Southern Africa, 35 (6): 839-851, https://doi.org/10.1080/0376835X.2018.1502075

NEL, H., \& PRETORIUS, E. 2012. Applying appreciative inquiry in building capacity in a nongovernmental organisation for youth: An Example from Soweto, Gauteng, South Africa. Social Development Issues, 34(1): 37-55.

PATEL, L. 2015. Social welfare and social development in South Africa ( $2^{\text {nd }}$ ed). Cape Town: Oxford University Press.

PREECE, J. 2017. Community engagement and lifelong learning: The Porous .

PRETORIUS, E., \& NEL, H. 2012. Reflections on the problem-based approach and the asset-based approach to community development. The Social Work Practitioner-Researcher/ Die Maatskaplikewerk Navorser-Praktisyn, 24 (2): 266-87.

REPUBLIC OF SOUTH AFRICA. 1996. Constitution of the Republic of South Africa, 1996. [Online] Available: https://www.gov.za/documents/constitution-republic-south-africa-1996. [Accessed: 03/09/2019]

REPUBLIC OF SOUTH AFRICA. 1998. The White Paper on Local Government: 9 March1998. [Online] Available: $\quad$ :http://www.CoGTA.gov.za/cgta_2016/wpcontent/uploads/2016/06/whitepaper_on_Local-Gov_1998.pdf. [Accessed: 03/09/2019]

REPUBLIC OF SOUTH AFRICA. 2000. Local Government: Municipal Systems Act, 2000: [Online] Available: https://www.gov.za/sites/default/files/gcis_document/201409/a32-000.pdf. [Accessed: 10/09/2019].

SCHENCK, R. NEL, H., \& LOUW, H. 2010. Introduction to participatory community practice. Pretoria: UNISA Press.

SSEWAMALA, F. M., SPERBER, E., ZIMMERMAN, J.M., \& KARIMLI, L. 2010. The potential of asset-based development strategies for poverty alleviation in Sub-Saharan Africa. International Journal of Social Welfare, 19: 433-443.

STRYDOM, H., \& DELPORT, C.S.L. 2011. Information collection: Document, study and secondary analysis. In: DDE VOS, A.S., STRYDOM, C.B., \& DELPORT, C.S.L. (eds). Research at grass roots. For the social sciences and human service professions $\left(4^{\text {th }}\right.$ ed). Pretoria: Van Schaik Publishers.

SWANEPOEL, H., \& DE BEER, F. 2011. Community development: Breaking the cycle of poverty $\left(5^{\text {th }}\right.$ ed). South Africa: Juta Publishers.

WEYERS, M.L. 2016. The theory and practice of community work: A South African perspective. Potchefstroom: Keurkopie, Second Edition. 
WHITE PAPER FOR SOCIAL WELFARE, NOTICE 1108 OF 1997. Government Gazette, number 18166, Volume 386: Pretoria: Government Printer.

WHITNEY, D., TROSTEN-BLOOM, A., \& RADER, K. 2010. Appreciative leadership. New York: McGraw Hill.

WORLD BANK, 2010. Accountability in public services in South Africa: Selected issues. The World Bank

YENEABAT, M., \& BUTTERFIELD, A.K. 2012. Part 3: Practice; "We can't eat a road:” Asset-based community development and the Gedam Sefer Community Partnership in Ethiopia. Journal of Community Practice, 20: 134-153.

REPUBLIC OF SOUTH AFRICA. 1996. Constitution of the Republic of South Africa, 1996. [Online] Available: https://www.gov.za/documents/constitution-republic-south-africa-1996. [Accessed: 2019-09-03]

REPUBLIC OF SOUTH AFRICA. 1998. The White Paper on Local Government: 9 March1998. [Online] Available: :http://www.CoGTA.gov.za/cgta_2016/wpcontent/uploads/2016/06/whitepaper_on_Local-Gov_1998.pdf. [Accessed: 2019-09-03]

REPUBLIC OF SOUTH AFRICA. 2000. Local Government: Municipal Systems Act, 2000: [Online] Available: https://www.gov.za/sites/default/files/gcis_document/201409/a32-000.pdf. [Accessed: 2019-09-10] 